\title{
大腸菌リン脂質の分子生物学†
}

\author{
渋 谷 重
}

(埼玉大学理学部)

大晹菌（Escherichia coli K-12）は原核単細胞生物で あるため，研究材料としての当然の限界があるが，他 万，その相対的単維さ之知見・技術の蓄積を利用し，分 子遺伀学的な手法によって膜・リン脂質にかかわる生物 共通の原理をまず大腸菌について理解しよらといら努力 が成果を収めつつある. 本稿では，大腸菌の主要りン脂 質についての知見を整理し，各リン脂質の生合成制御の 機構と生理的役割についての課題と現状を述べたい，詳 細な知見は総説 ${ }^{(1-3)}$ に譲って文献の引用は主要なるのの みにとどめた、归脂質地酵素の略号, 遗伝子名などは 図1にまとめて示したので参照願いたい。

\section{1. 分子遗伝学的アプローチの現状}

大腸菌細胞でリン脂質はもっぱら細胞質膜拉よび外膜 の基本成分として存在し，生合成の場は細胞質膜である。

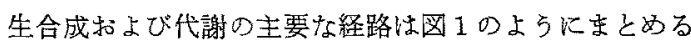
ことができる，真核生物に較べて著しく単純であるとい 克よら・分子遭伝学的アプローチの主要な目的の 1 つは, 各リン脂質の生合成を遺伝学的に改变し，リン脂質組成 が野生型と翼なる細胞を構䓩することによって膜機能・

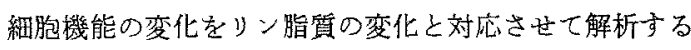
ことにある. 各主要りン脂質の生合成は，それぞれの開 始過程の改变によって操作できるので，図1の各反心応の なかでも，PS，PGP および CL シンターゼの各酵索と それらの構造遗后子 $p s s A$, pgs A および cls にとくに関 心が持たれている，図2は，その上うな研究結果の象耀 として，各開始過程遺伝子と培盖条件の操作によるリン 脂質組成のさまざまな改変を示したものである。

これまで，生体膜の脂質組成は膜の種類によってほぼ 一定で,そのことが膜の正常な機能発現に必要であるら と想定されてきた.しかしなか゚ら，大腸菌での遗伝学的

$\uparrow$ Molecular Biology of Phospholipids in Escherichia coli.

Isao SHIBUYA (Department of Biochemistry, Saitama University, Urawa 338)
改変の結果は子想を覆すものであり，リン脂質組成，ひ いては膜棈造に対する細胞の要求は驚くはど柔軟で, 野 生型とは大幅に異なる組成であっても生存に必須な膜機 能が発揮されるようにみ光（図 2)，それでは，大腸菌 にとってリン脂質は何でもよく，機能のらえで極性基構 造の特異性はないのだろらか? その後の詳細な解析 は、しつはそうではないことを示しつつある.

リン脂質生合成変異株の生育能，換恶すればあるリン 脂質の必要合成速度は，細胞の置かれた環境すなわち

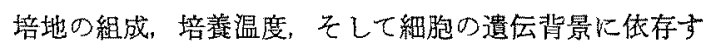
る部分が大きいことがわかってきた。たと泣，pgsA 遗伝子の完全欠損変異株は生存できないが(10), 酸性りン 脂質 $\mathrm{PG}$ および CL をわずかに生成する pgsA3 变異株 の生育は，成熟に PG 1 分子を消費する外膜の主要リン

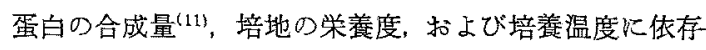
する，主要リポ蛋白の合成が野生型であると，基質 PG の不足のため前駆体の修飾速度が低下し，膜電位が消失 して細胞は死減する。これは，分泌経路の停滞によって 分泌蛋白前駆体のシグナル領域が膜へ非特異的に塖入す ることによるるのと想像される。ここでの PG の役割 は，同じ酸性リン脂質でる PAやPIで代替できない， しかし，栄養的に貧困な培地で生育速度が著しく低いと

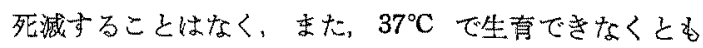
$42^{\circ} \mathrm{C}$ では生育する. 高温の抑制効果は，PG上り約 $30^{\circ} \mathrm{C}$ 相転移温度が高い $\mathrm{PE}$ を主成分とする pgsA 3 変異株て は，適切な膜の流動性の確保に高温が必要だからである 5.

CL シンターゼの構造遗伝子 $c l s$ の完全欠損变異株て も，CL は微量ながら合成され，生育はほぼ正常である。 PS シンターゼの温度感受性変暴 $p S S A 1$ を導入してこの 酵素の活性を低下させると，PS 合成にはあまり影響し ない条件で CL 含量はさらに低下し生育が困難になる このことは，PS シンターゼが副反応として CL も生成

L, CL に特異的化存する必須の膜機能が存在するこ 


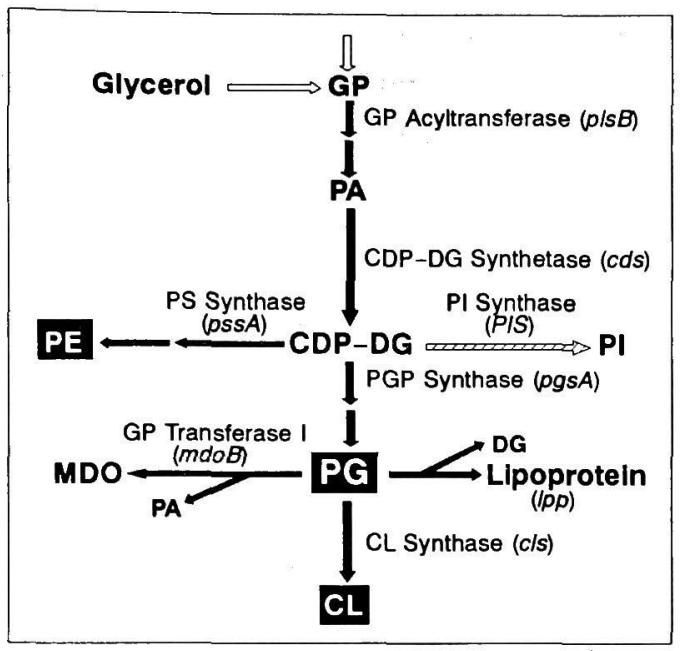

図 1 大腸菌におけるリン脂質生合成と 消費の主要経路 (黒矢印)

白抜きが主要りン脂質. PI はパン醅母の PI シン ターゼ構造遗伝子 PIS を myo-イノシトール存在 下で発現させた場合に生成. 括弧内は各䤃素の構造 遺伝子名. 略号 : GP, sn-glycerol 3-phosphate; PA, phosphatidic acid; CDP-DG, CDP-diacylglycerol ; PI, phosphatidylinositol ; PS, phosphatidylserine; $\mathrm{PE}$, phosphatidylethanolamine; PGP, phosphatidylglycerophosphate ; PG, phosphatidylglycerol; $\mathrm{CL}$, cardiolipin ; MDO, membrane-derived oligosaccharides.

とを示唆するもので, このような二重变異株は CL の特 異的機能の検索にきわめて有用である.

一方, pssA I 変異株の高温での生育は培地の浸透圧と $\mathrm{Mg}^{2+}$ 濃度に依存する(6). $\mathrm{Mg}^{2+} 20 \mathrm{mM}$ を含む $\mathrm{LB}$ 培地 では，PEをまったく生成しないpss A 完全欠損株も生 育できる(5)。したがって，PE の役割が酸性リン脂質と 異なり，主としてマトリックスレベルのものであること が推定され，同時に酸性りン脂質では $\mathrm{Mg}^{2+}$ を必要とす ろ非二重層構造の重要性が示唆される.

このような遗伝学的改变株の解析によって，それぞれ のリン脂質の細胞機能における役割の理解が蓄積しつつ ある、そのなかでの 1 つの単純な結論は，野生型株より 生育をよくする，すなわら細胞にとってより好都合な改 変はない，といらことである. 過酷な自然界でる最も生 存に適するように進化してきたのが, 現在の野生型リン 脂質組成なのであろう.

分子遺伝学的アプローチの有用性のも51つの柱は, 遺伝子のクローニングによる産物の増幅生産の道が開け ることである.リン脂質合成酢素は，構成的で細胞内濃

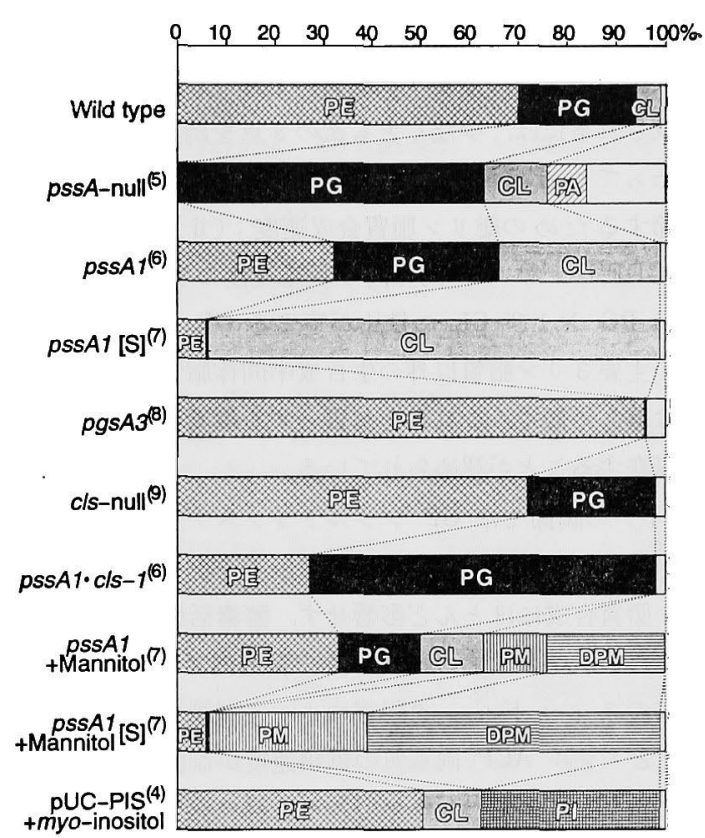

図 2 大腸菌リン脂質組成の遗伝学的改変 代表的な欠損变異保持株の対数增殖期または静止 期（S）におけるリン脂質組成を脂質リンモル\%で 示す．総りン脂質含量はこれらの株で顕著な差はな い. + Mannitol は培地に $20 \mathrm{mM} \mathrm{MgCl}$ と $600 \mathrm{mM}$ D-mannitol を加えた場合で, PM は phosphatidylmannitol, DPM は diphosphatidylmannitol でそ れぞれ PG および CL のアナログである. pUCPIS はパン酵母の PIS 遺伝子を $\operatorname{lac} P$ 下流に持つ pUC 誘導体 ${ }^{(4)}$.

度が低く，蹯水性のため精製が困難なるのが多く，加克 て脂質を基質とする反応の宿命である動力学的解析の困 難さのため, リン脂質生合成の䤉素学的研究は著しく遅 れていたが，構造遺伝子の発現增幅によって精製，解析 が可能になりつつある.

\section{2. リン脂質の生合成と代謝の制御}

大腸菌細胞にとって野生型のリン脂質組成が最も都合 がいいとすれば，細胞はそれを実現，保持するための仕 組みを備学ているであらう，その上うな仕組みの解明に も. 分子遺伝学的アプローチは不可欠である. 大腸菌に は，山下らがパン酵母で明らかにしつつあるような生合 成䤃素遗伝子の転写制御機構（本シリーズ参照）はまだ 見出されていない．欠損によってPS シンターゼとジア シルグリセロールキナーゼの活性を 5 倍程度化上昇させ る遗伝子 $p s s R$ および $d g k R$ が Raetz らによって発見さ れているが，それらの生物学的意義は現時点では不明で 
两る。

大腸菌で3つの主要りン脂質がそれでれ適切な速度で 合成されるには，少なくとも次の 3 点を調節する機構が 備わっていると予湘される：(i) 膜中蛋白との割合を 調節するための総りン脂質合成速度；(ii）生合成分岐 点 CDP-DG からの両方向の反応速度の割合；就よ゙ （iii） PG および CL の量比が定まる CL 合成反応. 通 常, 主要 3 リン脂質以外の生合成中間体脂質の膜中レベ ルは著しく低く，これらを基質とする醉絜の活性は過㮃 に存在することが認められている。

（i）の調節では GP アシルトランスフェラーゼの反 応が第一候補であるが，pls $B$ 遺枩子発現を増幅しても リン脂質合成にほとんど影響せず，酵素活性が律速因子 ではない。この反応の基質 GP の細胞内プールは，その 合成のフィードバック阻害によって調節されて损り， GP とフンル ACP 両基質の供給速度が制御因子である ラ.ただし，細胞内 GP レベルの上后のみではりン脂質 合成は㩆進せず，アシル ACP 生成速度の操作にはま块 成功していないので，この点はまだ推定の域を出ない，

(ii）の分配の調節も、関与するPS シンターゼ扰よ び PGP シンターゼの活性レでルによるるのでないこと は，これらの遗伝子工学的增幅がリン脂質組成汇ほとえ ど影響を与兄ないことから明らかである. CDP-DG か らの両方向への分配は, $p l s B$ および $g p s A$ 欠損株での巽 なる濃度のグリセロール添加実験の結果から, 両シンタ 一ゼの特性に基づき CDP-DG 生成速度に上り決定され ると考克られる，最適条件以下の基質供給では酸性リン 脂質が優先的化合成されるが，こ机は脂質関連醉素のな かでPS シンターゼのみが細胞質に存在し，反応の際だ け膜と結合することにより可能となるもので，酸性りン 脂質が極性基種特異的な役割を持つことから，細胞比之 って合目的性を持つ調節機構であると推定される.

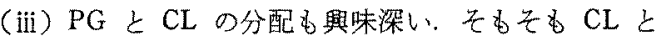
いらリン脂質がどのような特暴的役割を持つかという点 が理解できていないが，乥の合成は制垠されているらし い. 野生型細胞の対数增殖期では大量の PG が存在す るにるかかわらず CL 含量は全少脂質の約 $5 \%$ にと どまる（図 2). CL 合成は他のリン脂質合成と異なり， $\mathrm{CL}$ シンターゼの活性にも部分的に依存するが，醅素活 性の增幅に比例して增大することはない(12)，CL 合成 は，細胞の生育静止期や呼吸機能が低下するような諸条 件下， PE 合成久損条件 ( $p s s A 1$ p pss A 完全欠損株),
あるいは CDP-DG の添加によって著しく増大すること が知られてお゙り，また緊縮制御の対象となるといら報告 出㐫る.これらの現象分子レべルで理解するには， CL シンターゼの精製と解析が必須であるが，これまで どの生物からる精製されていなかった，最近，大腸菌の 酵素の高度増幅经上る精製と有用な活性測定法の開発が 行われたので12，上記諸現象の分子機序の解析が可能と なった。

\section{3. 膜リン脂質の生理的役割}

この数年, in vitro 系で次のよらないくつかの重要な 生理活性へのリン脂質のかかわりを示唆する観察が報告 ざれ，これまで膜脂質の研究で最る逢れていた機能面一 の関心が急速に高音りつつある。

(1) DNA 複製：複製の開始拈よび終始領域と外膜と の結合は，娘 DNA の分配との関連で以前から注目され ていたが，最近，複製開始にかかわる DnaA 蛋白の再活 珄化に酸性リン脂質が必要であるこど(1)や，複製直後の 半メチル化型開始領域と細胞質膜の特異的結合 ${ }^{(14)}$ など か゚見出され，リン脂質が複製反応自体の制御仍かわ。 可能性が指摘されている. Norris は DNA 複製開始を はじめとする細胞の周期がすべて酸性りン脂質の所在部 位の急変に基づくといら大胆なモデルを提唱しだ(15). 現 存の知見亡矛盾する面もかるが，発想はニニークで実駼 的吟味に值すると考学られる。

(2) ストレス応答：DNA の損傷などを諉因として発 動されるSOS 応答の主役 RecA 蛋白は，発動時江膜と 結合するが，これは RecA が酸性りン脂質と特異的な結 合能を有し機能が变化するためと考えられる ${ }^{(18)}$. 一方, 多くの状況証拠加ら，リン脂質欠損の表現型が熱ショッ クや SOS など， 細胞のストレス応答機能と密接にかか わっている可能性が高い。

(3) 蛋白質分泌：膜がかかわる現象として，蛋白質の 分泌機構についての研究が現在精力的汇行われている. そのなかで，酸性リン脂質欠損株からの反転小胞では外 膜蛋白 PhoE $の$ 前駆体の膜内移動が低下し，酸性りン脂

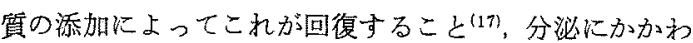
る蛋白質の5ち SecA の膜内移動に伴う ATP フーゼ 活性に酸性リン脂質が必要であること敫などが観察さ れている、また，蛋白質分泌などの膜のダイナミックな 機能に，膜脂質の非二重層化（局部的，一次的なへキ+ ゴナル $\mathrm{H}_{\text {II }}$ 相の生成) の重要性が指摘され，分泌蛋白 のシグナル領域によるこの相変化がモデル実験で観察ざ 
れている(19).

膜りン脂質が，膜翰送や呼吸能の上5な典型的な膜の 機能だけでなく、これまで膜とは無縁のるのと考えられ てきた細胞の中枢機能にもかかかっていること京㖫す るデータが蓄積されつつある，しかしながら，その上ら な観察はまだ主として in vitro のモデル系によるもの で，真の生物学的意義は明らかでないものが多い。この 時点で有効かつ必要なアプローチが分子遗伝学的手法で あり，上述の遗伝学的改变株などを活用した in vivoで の解析が急がれる、複雑な系で真の解を得るには，in vivo と in vitro 両面からの総合的な研究が不可欠であ ることはこえまでの生物科学の歴史も明白に教えてい るからである。

(1) J.E. Cronan, Jr. and C. O. Rock: "Escherichia coli and Salmonella typhimurium. Cellular and Molecular Biology," Vol.1, ed. by F.C. Neidhardt, American Society for Microbiology, Washington, D. C., 1987, p. 474.

(2) T. Vanden Boom and J. E. Cronan, Jr.: Annu. Rev. Microbiol., 43, 317 (1989).

(3) I. Shibuya : Prog. Lipid Res., in press.

(4) J. Nikawa, T.Kodaki and S. Yamashita: J. Bacteriol, 170, 4727 (1988).

(5) A. DeChavigny, P. N. Heacock and W. Dowhan : J. Biol. Chem., 266, 5323 (1991).

(6) I. Shibuya, C. Miyazaki and A. Ohta: $J$. Bacteriol., 161, 106 (1985).
(7) I. Shibuya, S. Yamagoe, C. Miyazaki, H. Matsuzaki and A. Ohta: $J$. Bacteriol., 161, 473 (1985).

(8) C. Miyazaki, M. Kuroda, A. Ohta and I. Shibuya : Proc. Natl. Acad. Sci. U.S.A., 82, 7530 (1985).

(9) S. Nishijima, Y. Asami, N. Uetake, S. Yamagoe, A. Ohta and I. Shibuya: J. Bacteriol., 170, 775 (1988).

(10) P. N. Heacock and W. Dowhan: J. Biol. Chem., 262, 13044 (1987).

(11) Y. Asai, Y.Katayose, C. Hikita, A. Ohta and I. Shibuya: J. Bacteriol., 171, 6867 (1989).

(12) S. Hiraoka, K. Nukui, N. Uetake, A. Ohta and I. Shibuya: J. Biochem., 110, 443 (1991).

(13) B. Y.-M. Yung and A. Kornberg: Proc. Natl. Acad. Sci. U.S. A., 85, 7202 (1988).

(14) A. Landoulsi, A. Malki, R. Kern, M. Kohiyama and P. Hughes : Cell, 63, 1053 (1990).

(15) V. Norris: $J$. Theor. Biol., 139, 117 (1989) ; J. Mol. Biol., 214, 1 (1990).

(16) P. Krishna and J. H. van de Sande: $J$. Bacteriol., 172, 6452 (1990).

(17) R. Kusters, W. Dowhan and B. de Kruijff: J. Biol. Chem., 266, 8659 (1991).

(18) R. Lill, W. Dowhan and W. Wickner : Cell, 60, 271 (1990)

(19) G.J.de Vrije, A.M. Batenburg, J.A. Killan and B. de Kruijff : Mol. Microbiol., 4, 143 (1990). 